\title{
Analisis Dampak Alih Fungsi Lahan terhadap Tingkat Ketahanan Pangan Rumah Tangga Petani di Karanganyar, Jawa Tengah
}

D 0 I:10.18196/ agr.1213

\begin{abstract}
The aim of this study were to identify the sources of household income and to analyze factors that influence the accessibility of food of household food rice farmers who are not converted and converted their land. The study was conducted in Karanganyar with sample area was Colomadu District. The analysis technique used was description to identify the sources of household income and two different test mean used to determine whether there are differences in average income from various sources between households who did not convert and those who converted their land function. Logit regression was used to analyze the factors that influence the accessibility of food expenditure. The results on sources of household income
\end{abstract}

showed that most households of both have the main income from farming and self-employed. The monthly average income of farm households who were not converted their land greater than households who converted their land. Land convertion, age, number of household members and assets have significant effect on household food accessibility, while farm income and household income were not significant.

Keywords: agricultural land convertion, sources of household income, food accessibility.

\section{INTISAR I}

Tujuan penelitian ini mengidentifikasi sumber pendapatan rumah tangga serta menganalisis faktor yang mempengaruhi pengeluaran pangan dan aksesibilitas pangan rumah tangga petani padi yang tidak beralih fungsi lahan dan yang melakukan alih fungsi. Penelitian dilakukan di Kabupaten Karanganyar dengan sampel daerah adalah Kecamatan Colomadu. Teknik analisis yang digunakan adalah diskripsi untuk mengidentifikasi sumber pendapatan rumah tangga dan uji beda dua mean untuk mengetahui apakah ada perbedaan rata-rata pendapatan dari berbagai sumber antara rumah tangga petani yang tidak beralih fungsi dan yang melakukan alih fungsi. Untuk mengetahui faktor yang mempengaruhi aksesibilitas pangan dianalisis dengan regresi logit. Hasil penelitian mengenai sumber pendapatan rumah tangga menunjukkan sebagian besar rumah tangga tidak alih fungsi maupun alih fungsi lahan, mempunyai pendapatan utama dari usahatani dan wiraswasta. Rata-rata pendapatan sebulan dari usahatani untuk rumah tangga tidak alih fungsi lahan lebih besar dibanding rumah tangga alih fungsi. Alih fungsi lahan, umur, jumlah anggota rumah tangga dan aset signifikan berpengaruh terhadap aksesibilitas pangan rumah tangga, sedangkan pendapatan usahatani dan pendapatan rumah tangga tidak signifikan.

Kata kunci: alih fungsi, sumber pendapatan rumah tangga, aksesibilitas pangan. 


\section{PENDAHULUAN}

Peningkatan penduduk dan taraf hidup masyarakat mengakibatkan meningkatnya kebutuhan lahan untuk pemukiman atau kegiatan ekonomi lainnya. Kebutuhan lahan ini kemudian mengambil lahan sawah produktif yang sarana dan prasarananya baik, dan umumnya lokasinya dekat perkotaan. Dampak alih fungsi lahan secara makro adalah ketersediaan pangan yang berkurang dan berakibat pada berkurangnya ketahanan pangan secara nasional. Secara mikro, alih fungsi lahan mengakibatkan petani yang semula mengusahakan tanaman pangan dan dapat memenuhi sendiri ketersediaan pangan (beras) bagi rumah tangganya menjadi tidak memiliki beras dan harus membeli. Dampak lain dari alih fungsi lahan adalah hilangnya mata pencahariannya sebagai petani. Seperti dinyatakan Afandi (2011) bahwa dampak alih fungsi lahan sawah menyebabkan petani kehilangan pendapatan dari berusaha tani. Dari segi produksi, dengan terkonversinya lahan sawah maka akan menghilangkan hasil produksi pertanian sebanyak luas lahan yang terkonversi, Kerugian lain menurut Afandi adalah hilangnya kesempatan kerja pada usaha tani, serta peluang pendapatan dan kegiatan ekonomi yang berhubungan dengan usaha tani, seperti asaha penyediaan saprotan, alsintan, penggilingan padi, penyewaan traktor.

Irawan (2005) menyatakan adanya alih fungsi lahan, akan menghilangkan pendapatan para petani, baik petani pemilik, penyewa, penggarap maupun buruh tani yang menggantungkan hidupnya dari usaha tani. Apabila alih fungsi lahan, terutama lahan sawah produktif yang banyak menyerap tenaga kerja, maka akan terjadi penurunan kesempatan kerja, dan selanjutnya berdampak pada penurunan pendapatan para petani. Dengan menurunnya pendapatan maka daya beli menurun dan berdampak pada menurunnya aksesibilitas ekonomi rumah tangga petani terhadap pangan. Menurut Santosa, dkk. (2011) alih fungsi lahan sangat sulit dihentikan, bahkan cenderung meningkat dengan luas yang semakin banyak, dan ini sangat berpengaruh pada ketahanan pangan.

Penelitian mengenai alih fungsi lahan dan dampaknya pada tingkat ketahanan pangan rumah tangga belum banyak dilakukan oleh peneliti. Ginting (2005) meneliti tentang dampak alih fungsi lahan terhadap pendapatan petani di desa Munte Kabupaten Karo Sumatera Utara. Hasil penelitin tersebut menunjukkan bahwa alih fungsi lahan sawah telah menjadikan petani mengganti komoditi yang ditanam dari padi sawah ke komoditi non padi sawah, sehingga berdampak pada penurunan pendapatan petani.

Secara nasional, petani tanaman pangan menjadi subyek yang penting dalam ketersediaan pangan. Hal ini karena pemerintah mencanangkan kemandirian pangan melalui swasembada pangan. Namun meningkatnya alih fungsi lahan pertanian produktif akan berdampak pada ketersediaan pangan secara wilayah dan secara nasional. Alih fungsi lahan juga kemungkinan berdampak pada menurunnya tingkat kesejahteraan petani, atau berkurangnya ketahanan pangan rumah tangga petani. Dengan demikian perlu diteliti tingkat ketahanan pangan rumah tangga petani antara yang alih fungsi lahan dan yang tidak melakukan alih fungsi.

Petani yang tidak melakukan alih fungsi, maka mereka merupakan aktor penting dalam ketersediaan pangan, sehingga perlu diidentifikasi tingkat ketahanan pangan rumah tangganya dan faktor yang mempengaruhinya. Fakta empiris menunjukkan petani yang menanam beras, membeli beras karena kekurangan beras. Keadaan ini diduga disebabkan sedikitnya produksi yang membawa akibat pada kekurangan ketersediaan pangan secara fisik. Atau bila semua hasil panennya dijual, dengan sedikitnya produksi maka pendapatan dari hasil panen juga sedikit. Implikasi selanjutnya adalah keterbatasan daya beli atau keterbatasan akses pangan secara ekonomi. Selanjutnya bagi petani yang sudah melakukan alih fungsi, kemungkinan berdampak pada menurunnya tingkat ketahanan pangan.

Penelitian ini mengidentifikasi ketahanan pangan rumah tangga petani yang beralih fungsi dan yang tidak alih fungsi. Tingkat ketahanaan pangan dilihat dari aspek akses pangan secara ekonomi. Fokus penelitian adalah faktor yang mempengaruhi akses rumah tangga terhadap pangan. Penelitian mengenai akses pangan para rumah tangga petani tanaman pangan urgen untuk dilakukan, mengingat kedudukan strategis petani tanaman pangan dalam ketersediaan pangan secara nasional, namun dihadapkan pada meningkatnya alih fungsi lahan produktif. Penelitian dilakukan di Kabupaten Karanganyar dengan sampel daerah adalah Kecamatan Colomadu. Kecamatan Colomadu diambil sebagai daerah penelitian dikarenakan banyaknya lahan produktif yang ditanami padi dan letaknya dekat perkotaan yaitu bersebelahan dengan Kota Solo bagian barat. Berkembangnya Kota Solo menyebabkan banyak 
lahan produktif di Kecamatan Colomadu beralih fungsi untuk pemukiman dan industri.

\section{METODE}

Penelitian ini menggunakan metode survei dengan unit analisis adalah rumah tangga petani padi yang tidak beralih fungsi lahan dan yang melakukan alih fungsi lahan. Jumlah sampel terdiri 100 rumah tangga yang tidak beralih fungsi dan 100 rumah tangga petani yang beralih fungsi. Teknik analisis yang digunakan adalah diskripsi untuk mengidentifikasi sumber pendapatan rumah tangga dan uji beda dua mean untuk mengetahui apakah ada perbedaan rata-rata pendapatan dari berbagai sumber antara rumah tangga petani yang tidak beralih fungsi dan yang melakukan alih fungsi lahan. Untuk mengetahui faktor yang mempengaruhi pengeluaran pangan dianalisis dengan regresi berganda (persamaan 1). Untuk mengetahui faktor yang mempengaruhi aksesibilitas pangan dianalisis dengan regresi logit (persamaan 2). Regresi berganda dan regresi logit masingmasing dilakukan terhadap 3 persamaan regresi, persamaan seluruh rumah tangga, rumah tangga tidak alih fungsi dan rumah tangga alih fungsi lahan.

$$
\text { LPANGi }=\text { ai + bi ALIH + ci LUM + di LJANG + ei DIK }
$$$$
\text { + fi LPUSTAN + gi LPEND + hi LASET + vi }
$$

\section{KETERANGAN :}

LPANGi : Log pengeluaran pangan rumah tangga ke i dimana $\mathrm{i}=1,2,3 \mathrm{i}=$ 1 seluruh rumah tangga $; i=2$ rumah tangga tidak alih fungsii $=3$ rumah tangga alih fungsi

ALIH : Alih fungsi lahan tidak alih $=1 ;$ alih $=0$

LUM : Log umur

LANG : : Log jumlah anggota rumah tangga

DIK : Tingkat pendidikan SMA ke atas $=1 ;$ SMP ke bawah $=0$

LPUSTAN : Log pendapatan usahatani

LPEND : Log pendapatan rumah tangga

LASET : : Log asset

a : Konstanta

$\mathrm{b}, \mathrm{c}, \ldots . \mathrm{h} \quad$ : Koefisien regresi

$\mathrm{v} \quad$ : Variabel pengganggu

$$
\ln \frac{P i}{1-P i}=A P i=\text { aai }+ \text { bbi ALIH }+ \text { cci UM + ddi }
$$

JANG + eei DIK + ffi PUSTAN + ggi PEND + hhi ASET

$$
+ \text { vvi (2) }
$$$$
\text { KETERANGAN : }
$$

APi : Aksesibiltas pangan rumah tangga ke I dimana $\mathrm{i}=1,2,3 \mathrm{Akses}$ baik $=1$; akses tidak baik $=0 \mathrm{i}=1$ seluruh rumah tangga $; i=2$ rumah tangga tidak alih fungsii $=3$ rumah tangga alih fungsi

ALIH $\quad$ : Alih fungsi lahan tidak alih $=1$; alih $=0$

UM : Umur (tahun)

JANG : jumlah anggota rumah tangga (orang)

DIK : Tingkat pendidikan SMA ke atas $=1 ;$ SMP ke bawah $=0$

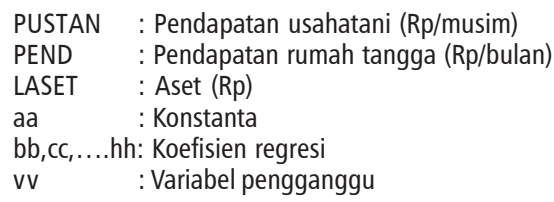

Aksesibilitas pangan (AP) adalah akses rumah tangga terhadap pangan diukur secara katagori, baik dan tidak baik. Indikator yang digunakan adalah proporsi pengeluaran pangan dari pengeluaran total rumah tangga, dengan cutting point sebesar $60 \%$ dari pengeluaran total rumah tangga. Cutting point ini menggunakan sebagian indikator Johnson dan Toole (1991), yang diadopsi oleh Maxwell et al., (2000). Bila proporsi pengeluaran pangan $<60 \%$ dari pengeluaran total maka dinyatakan akses rumah tangga terhadap pangan adalah baik, dan sebaliknya bila proporsi pengeluaran pangan e" 60\% dari pengeluaran total, dinyatakan akses tidak baik.

\section{HASIL PEMBAHASAN KARAKTERISTIK RESPONDEN}

Rata-rata umur responden menurut alih fungsi menunjukkan pada rumah tangga tidak alih fungsi adalah 64 tahun dan rumah tangga alih fungsi adalah 66 tahun. Rata-rata jumlah anggota rumah tangga, baik rumah tangga tidak alih fungsi maupun alih fungsi sebanyak 2 orang. Menurut jenis kelamin, sebagian besar responden adalah laki-laki (90\% rumah tangga tidak alih fungsi dan 93\% rumah tangga alih fungsi). Menurut alih fungsi lahan, sebagian besar responden yang tidak alih fungsi adalah SD (49\%), sebagian besar responden yang alih fungsi adalah SMP (50\%).

Sebagian besar lokasi lahan sawah responden yang dialihfungsikan adalah di dekat perumahan (67\%). Ratarata luas lahan yang dialih fungsikan adalah $2.628 \mathrm{~m}^{2}$ dengan rata-rata nilai lahan sebesar Rp 689,470 juta. Tingginya nilai lahan ini sejalan dengan cepatnya perkembangan pemukiman dan perindustrian di daerah Kecamatan Colomadu. Kecepatan laju alih fungsi ini ditunjang dengan lokasi kecamatan Colomadu yang dekat dengan daerah Surakarta bagian barat. Semakin berkembangya Surakarta, akan berdampak pada semakin cepatnya perkembangan kecamatan Colomadu menjadi daerah pemukiman dan perindustrian. Lama responden mengalihfungsikan lahan rata-rata sudah selama 4,4 tahun atau alih fungsi terjadi sekitar tahun 2008-2009.

Distribusi responden menurut aksesibilitas pangan dan alih fungsi lahan menunjukkan sebagian besar 
TABEL I. DISTRIBUSI RESPONDEN MENURUT ALIH FUNGSI LAHAN DAN AKSESIBILITAS PANGAN

\begin{tabular}{lllllll}
\hline \multirow{3}{*}{ Alih Fungsi Lahan } & \multicolumn{3}{l}{ Aksesibilitas Pangan } & \multirow{2}{*}{ Total } \\
\cline { 2 - 5 } & Baik & \multicolumn{3}{l}{ Tidak } & \\
\cline { 2 - 5 } & orang & $\%$ & Orang & $\%$ & Orang & $\%$ \\
\hline Tidak & 80 & 57,14 & 20 & 33,33 & 100 & 50,00 \\
Alih & 60 & 42,86 & 40 & 66,67 & 100 & 50,00 \\
Jumlah & 140 & 100,00 & 60 & 100,00 & 200 & 100,00 \\
\hline
\end{tabular}

\section{TABEL 2. RATA-RATA PENDAPATAN DARI BERBAGAI SUMBER MENURUT ALIH} FUNGSI LAHAN

\begin{tabular}{|c|c|c|c|c|c|c|}
\hline \multirow{3}{*}{ Keterangan } & \multicolumn{4}{|c|}{ Alih Fungsi Lahan } & \multirow{2}{*}{\multicolumn{2}{|c|}{ Total }} \\
\hline & \multicolumn{2}{|c|}{ Tidak } & \multicolumn{2}{|l|}{ Alih } & & \\
\hline & Rp/bulan & Orang & Rp/bulan & Orang & Rp/bulan & Orang \\
\hline Usaha tani & $1.593 .000^{* *}$ & 100 & $1.361 .667^{* *}$ & 100 & 1.477 .333 & 200 \\
\hline Buruh Tani & 664.219 & 96 & 665.464 & 97 & 664.845 & 193 \\
\hline Pegawai Negeri & 1.200 .000 & 1 & - & - & 1.200 .000 & 1 \\
\hline Wiraswata & 1.250 .000 & 2 & 1.400 .000 & 3 & 1.340 .000 & 5 \\
\hline Montir & - & - & 800.000 & 2 & 800.000 & 2 \\
\hline Sopir & 650.000 & 2 & - & - & 650.000 & 2 \\
\hline Pekerja Bangunan & 650.000 & 2 & 400.000 & 1 & 566.667 & 3 \\
\hline Pramuwisma & 800.000 & 1 & 600.000 & 2 & 666.667 & 3 \\
\hline Serabutan & 600.000 & 3 & 600.000 & 4 & 600.000 & 7 \\
\hline
\end{tabular}

Keterangan : ${ }^{* *}$ signifikan 5\% (t hitung 2,1981; probabilitas $\left.=0,0294\right)$

\section{TABEL 3. RATA-RATA PENDAPATAN DARI BERBAGAI SUMBER MENURUT AKSESIBILITAS PANGAN}

\begin{tabular}{|c|c|c|c|c|c|c|}
\hline \multirow{3}{*}{ Keterangan } & \multicolumn{4}{|c|}{ Aksesibilitas Pangan } & \multirow{2}{*}{\multicolumn{2}{|c|}{ Total }} \\
\hline & \multicolumn{2}{|l|}{ Baik } & \multicolumn{2}{|l|}{ Tidak } & & \\
\hline & Rp/bulan & Orang & Rp/bulan & Orang & Rp/bulan & Orang \\
\hline Usaha tani & $1.570 .476^{* * *}$ & 140 & $1.260 .000^{* * *}$ & 60 & 1.477 .333 & 200 \\
\hline Buruh Tani & $691.842^{* * *}$ & 133 & $605.500^{* * *}$ & 60 & 664.845 & 193 \\
\hline Pegawai Negeri & 1.200 .000 & 1 & - & - & 1.200 .000 & 1 \\
\hline Wiraswata & 1.340 .000 & 5 & - & - & 1.340 .000 & 5 \\
\hline Montir & 800.000 & 2 & - & - & 800.000 & 2 \\
\hline Sopir & 650.000 & 2 & - & - & 650.000 & 2 \\
\hline Pekerja Bangunan & 566.667 & 3 & - & - & 566.667 & 3 \\
\hline Pramuwisma & 666.667 & 3 & - & - & 666.667 & 3 \\
\hline Serabutan & 600.000 & 1 & 600.000 & 6 & 600.000 & 7 \\
\hline
\end{tabular}

Keterangan : ** signifikan $1 \%$ (t hitung usaha tani 3,6250 ; probabilitas 0,0004 dan $\mathrm{t}$ hitung buruh tani 3,4681; probabilitas 0,0007 ).

rumah tangga akses pangan baik adalah rumah tangga yang tidak melakukan alih fungsi lahan $(57,14 \%)$, sedangkan rumah tangga akses pangan tidak baik adalah rumah tangga yang melakukan alih fungsi lahan (66,67\%). Selengkapnya distribusi responden menurut alih fungsi lahan dan akses pangan disajikan pada tabel 1 .

\section{SUMBER PENDAPATAN RUMAH TANGGA}

Rata-rata pendapatan dari berbagai sumber pendapatan menurut alih fungsi lahan disajikan pada tabel 2. Menurut alih fungsi lahan, sebagian besar rumah tangga tidak alih fungsi maupun alih fungsi, mempunyai pendapatan yang bersumber dari usahatani dan wiraswasta. Rata-rata pendapatan sebulan dari usahatani untuk rumah tangga tidak alih fungsi sebesar Rp 1,593 juta dan rumah tangga alih fungsi sebesar $\mathrm{Rp}$ 1,362 juta. Secara statistik terdapat perbedaan rata-rata pendapatan antara kedua kelompok rumah tangga tersebut, rumah tangga tidak alih fungsi lebih besar dibanding rumah tangga alih fungsi. Temuan ini menarik, bahwa rumah tangga alih fungsi masih mengusahakan usahatani. Diduga mereka mengalihfungsikan sebagian lahan yang dimiliki, sehingga masih memiliki lahan pertanian yang dapat dibudidayakan. Temuan ini juga mengindikasikan masih terdapatnya lahan sawah garapan di derah penelitian yang masih dibudidayakan, sehingga masih dapat menjadi sumber pendapatan bagi petani. Selengkapnya rata-rata pendapatan dari berbagai sumber dan alih fungsi lahan disajikan pada tabel 2 .

Rata-rata pendapatan dari berbagai sumber pendapatan menurut aksesibilitas pangan disajikan pada tabel 3. Menurut aksesibilitas pangan, rumah tangga akses pangan baik mempunyai rata-rata pendapatan usahatani sebulan sebesar Rp 1,570 juta, sedangkan rumah tangga akses pangan tidak baik mempunyai rata-rata pendapatan usahatani sebulan sebesar Rp 1,260 juta. Secara statistik menunjukkan terdapat perbedaan rata-rata tersebut, (signifikan 1\%). Rata-rata pendapatan dari buruh tani rumah tangga akses pangan baik dan tidak baik, juga menunjukkan adanya perbedaan (signifikan 1\%). Dengan demikian rata-rata pendapatan dari pertanian (usahatani dan buruh tani) rumah tangga akses pangan baik lebih besar dibanding rumah tangga akses pangan tidak baik. Selengkapnya rata-rata pendapatan dari berbagai sumber dan akses pangan disajikan pada tabel 3 .

Hasil penelitian pada tabel 3 menunjukkan rumah tangga dengan akses pangan baik, mempunyai banyak sumber pendapatan selain dari usahatani, yaitu pegawai negeri, wiraswasta, montir, sopir, pekerja bangunan, pramuwisma dan serabutan. Rumah tangga dengan akses pangan tidak baik memiliki sumber pendapatan yang 
TABEL 3. RATA-RATA NILAI ASET MENURUT ALIH FUNGSI LAHAN

\begin{tabular}{|c|c|c|c|c|c|c|c|}
\hline \multirow{3}{*}{ Keterangan } & \multicolumn{4}{|c|}{ Aluh Fungsi Lahan } & \multirow{2}{*}{\multicolumn{2}{|c|}{ Total }} & \multirow{3}{*}{ Thitung } \\
\hline & \multicolumn{2}{|l|}{ Tidak } & \multicolumn{2}{|l|}{ Alih } & & & \\
\hline & $\mathrm{Rp}$ & Orang & $\mathrm{Rp}$ & Orang & $\mathrm{Rp}$ & Orang & \\
\hline Sapi & 23.000 .000 & 5 & 22.714 .286 & 7 & 22.833 .333 & 12 & 0,0734 \\
\hline Kambing & 10.400 .000 & 5 & 14.500 .000 & 2 & 11.571 .429 & 7 & 0,6959 \\
\hline Ayam & 766.667 & 3 & 800.000 & 2 & 780.000 & 5 & 0,0783 \\
\hline Spayer & 493.350 & 100 & 464.050 & 100 & 478.700 & 200 & 1,1461 \\
\hline Disel & 4.165 .000 & 100 & 3.843 .000 & 100 & 4.004 .000 & 200 & $1,6728^{*}$ \\
\hline TV & 770.833 & 96 & 736.316 & 95 & 753.665 & 191 & 0,7970 \\
\hline HP & 788.462 & 78 & 712.500 & 76 & 750.974 & 154 & 1,3409 \\
\hline Sepeda & 863.857 & 70 & 828.030 & 66 & 846.471 & 136 & 0,2162 \\
\hline Sepeda motor & 6.610 .000 & 100 & 6.765 .000 & 100 & 6.687 .500 & 200 & $-0,3541$ \\
\hline Emas & 1.800 .000 & 100 & 1.724 .000 & 100 & 1.762 .000 & 200 & 0,6883 \\
\hline Tabungan & 3.692 .000 & 100 & 223.571 .417 & 100 & 119.630 .000 & 200 & $-5,4761^{* * *}$ \\
\hline Uang Tunai & 315.800 & 100 & 368.100 & 100 & 341.950 & 200 & $-1,2337$ \\
\hline Jumlah Aset & 20.728 .850 & & 252.415 .650 & & & & $-5,4676^{* * *}$ \\
\hline
\end{tabular}

Keterangan : *** signifikan 1\%, * Signifikan 10\%

TABEL 4. RATA-RATA NILAI ASET MENURUT ALIH FUNGSI LAHAN

\begin{tabular}{|c|c|c|c|c|c|c|c|}
\hline \multirow{3}{*}{ Keterangan } & \multicolumn{4}{|c|}{ Aksesibilitas Pangan } & \multirow{2}{*}{\multicolumn{2}{|c|}{ Total }} & \multirow{3}{*}{ Thitung } \\
\hline & \multicolumn{2}{|l|}{ Baik } & \multicolumn{2}{|l|}{ Tidak } & & & \\
\hline & $\mathrm{Rp}$ & Orang & $\mathrm{Rp}$ & Orang & $\mathrm{Rp}$ & Orang & \\
\hline Sapi & 19.666 .667 & 6 & 26.000 .000 & 6 & 22.833 .333 & 12 & 1,8560 \\
\hline Kambing & 11.571 .429 & 7 & - & - & 11.571 .429 & 7 & - \\
\hline Ayam & 780.000 & 5 & - & - & 780.000 & 5 & - \\
\hline Spayer & 498.929 & 140 & 431.500 & 60 & 478.700 & 200 & $2,5787^{* *}$ \\
\hline Disel & 4.130 .000 & 140 & 3.710 .000 & 60 & 4.004 .000 & 200 & $2,5145^{* *}$ \\
\hline TV & 785.766 & 137 & 672.222 & 54 & 753.665 & 191 & $3,2694^{* * *}$ \\
\hline HP & 785.377 & 106 & 675.000 & 48 & 750.974 & 154 & $1,9074^{*}$ \\
\hline Sepeda & 967.273 & 88 & 625.000 & 48 & 846.471 & 136 & $2,6914^{* * *}$ \\
\hline Sepeda motor & 7.132 .143 & 140 & 5.650 .000 & 60 & 6.687 .500 & 200 & $4,5379^{* * *}$ \\
\hline Emas & 1.780 .000 & 140 & 1.720 .000 & 60 & 1.762 .000 & 200 & 0,5581 \\
\hline Tabungan & 169.477 .143 & 140 & 3.320 .000 & 60 & 119.630 .000 & 200 & $5,2789^{* * *}$ \\
\hline Uang Tunai & 363.357 & 140 & 292.000 & 60 & 341.950 & 200 & $3,4771^{* * *}$ \\
\hline Jumlah Aset & 186.802 .429 & & 19.368 .500 & & & & $5,3153^{* * *}$ \\
\hline
\end{tabular}

Keterangan : *** signifikan 1\%, ** Signifikan 5\%, ${ }^{*}$ Signifikan $10 \%$

terbatas, yaitu dari usahatani, buruh tani dan serabutan. Ini mengimplikasikan bahwa semakin banyak sumber pendapatan rumah tangga, semakin tinggi pendapatan dan berdampak pada semakin baik aksesnya terhadap pangan.

Kepemilikan aset rumah tangga menurut alih fungsi lahan disajikan pada tabel 3, menunjukkan rata-rata nilai aset rumah tangga tidak alih fungsi lebih kecil dibanding rumah tangga alih fungsi. Menurut jenis aset yang dimiliki, rata-rata nilai aset disel dan tabungan menunjukkan perbedaan antara rumah tangga tidak alih fungsi dan alih fungsi. Nilai disel rumah tangga tidak alih fungsi lebih tinggi dibanding rumah tangga alih fungsi. Nilai tabungan rumah tangga tidak alih fungsi lebih sedikit dibanding rumah tangga alih fungsi. Ini menunjukkan bahwa rumah tangga alih fungsi diduga masih menyimpan sebagian hasil penjualan lahannya dalam bentuk tabungan. 
Kepemilikan aset rumah tangga menurut akesibilitas pangan menunjukkan rata-rata nilai aset rumah tangga akses pangan baik adalah $\mathrm{Rp} 186,802$ juta, rumah tangga akses pangan tidak baik adalah Rp 19,368 juta, serta secara statistic terdapat perbedaan antara keduanya (signifikan 1\%). Ini berarti rata-rata nilai aset rumah tangga akses pangan baik lebih besar dibanding dengan rumah tangga akses pangan tidak baik. Selengkapnya ratarata nilia aset menurut alih fungsi lahan disajikan dalam tabel 4. Pengeluaran Pangan Rumah Tangga

Rata-rata pengeluaran rumah tangga menurut menurut aksesibilitas pangan disajikan pada tabel 5 . Hasil penelitian menunjukkan terdapat perbedaan rata-rata pengeluaran pangan, pengeluaran non pangan, jumlah pengeluaran dan proporsi pengeluaran pangan antara rumah tangga akses pangan baik dan rumah tangga akses pangan tidak baik (siginifikan 1\% dan $5 \%$ ). Rata-rata proporsi pengeluaran pangan rumah tangga akses pangan baik sebesar 0,4726 , sedang rumah tangga akses pangan tidak baik sebesar 0,6357.

\section{TABEL 5. RATA-RATA PENGELUARAN RUMAH TANGGA MENURUT ALIH FUNGSI LAHAN}

\begin{tabular}{|c|c|c|c|c|}
\hline \multirow{3}{*}{ Pengeluaran } & \multicolumn{2}{|c|}{ Aksesibilitas Pangan } & \multirow{2}{*}{ Total } & \multirow{3}{*}{ Thitung } \\
\hline & Baik & Tidak & & \\
\hline & Rp/bulan & Rp/bulan & Rp/bulan & \\
\hline Pangan & 464.071 & 681.600 & 529.330 & $12,878^{* * *}$ \\
\hline Non Pangan & 537.519 & 386.292 & 492.342 & $7,8680^{* * *}$ \\
\hline Jumlah & 1.001 .590 & 1.068 .529 & 1.021 .672 & $-2,4469^{* *}$ \\
\hline Proporsi Pengeluaran Pangan & 0,4726 & 0,5215 & 0,5215 & $19,8668^{* * *}$ \\
\hline
\end{tabular}

Pengeluaran pangan menurut komoditi pangan dan aksesibilitas pangan disajikan pada tabel 6 . Rata-rata pengeluaran beras rumah tangga akses pangan tidak baik lebih kecil dibanding rumah tangga akses pangan baik (signifikan 1\%). Selain beras yang merupakan pengeluaran dengan porsi besar, buah-buahan, makanan jadi dan mie instan juga merupakan porsi besar. Selengkapnya dapat dilihat pada tabel 6.

\section{PENENTU PENGELUARAN PANGAN}

Hasil analisis regresi berganda terhadap faktor penentu pengeluaran pangan untuk tidak alih fungsi, alih fungsi dan total rumah tangga disajikan pada tabel 7 . Hasil analisis regresi pengeluaran pangan terhadap rumah tangga tidak alih fungsi menunjukkan variabel umur signifikan berpengaruh positif dan pendapatan usaha tani signifikan berpengaruh negatif terhadap pengeluaran pangan, sedangkan jumlah anggota rumah tangga, tingkat pendidikan, pendapatan rumah tangga dan aset tidak signifikan. Semakin tua umur maka semakin tinggi pengeluaran pangan. Semakin tinggi pendapatan usahatani maka semakin rendah pengeluaran pangan. Selanjutnya hasil analisis regresi pengeluaran pangan terhadap rumah tangga alih fungsi menunjukkan variabel umur dan jumlah anggota rumah tangga signifikan berpengaruh positif terhadap pengeluaran pangan, sedangkan tingkat pendidikan, pendapatan rumah tangga dan aset tidak signifikan. Semakin tua umur, atau semakin banyak jumlah anggota rumah tangga, maka semakin tinggi pengeluaran pangan.

Hasil analisis regresi berganda terhadap faktor penentu pengeluaran pangan untuk total tumah tangga (tabel 7) menunjukkan variabel alih fungsi dan aset signifikan berpengaruh negatif, serta umur, jumlah anggota rumah tangga dan pendapatan rumah tangga signifikan berpengaruh positif terhadap pengeluaran pangan, sedangkan tingkat pendidikan dan pendapatan usaha tani tidak signifikan. Rumah tangga yang tidak alih fungsi mempunyai pengeluaran pangan lebih kecil dibanding rumah tangga alih fungsi. Semakin tinggi nilai aset yang dimiliki maka pengeluaran pangan akan semakin rendah. Semakin tua umur, atau semakin banyak jumlah anggota rumah tangga, atau semakin tinggi pendapatan rumah tangga maka pengeluaran pangan akan semakin tinggi. Temuan nilai aset berpengaruh negatif sesuai dengan hukum Engel, semakin tinggi kekayaan maka pengeluaran pangan akan berkurang.

\section{PENENTU AKSESIBILITAS PANGAN}

Hasil analisis regresi logit terhadap faktor penentu aksesibilitas pangan pada rumah tangga tidak alih fungsi, alih fungsi dan total rumah tangga disajikan pada tabel 8 . Hasil analisis regresi logit terhadap rumahh tangga tidak alih fungsi menunjukkan variabel umur, jumlah anggota rumah tangga, tingkat pendidikan, pendapatan usahatani adalah signifikan berpengaruh terhadap aksesibilitas pangan rumah tangga tidak alih fungsi (peluang akses pangan baik atau akses pangan tidak baik), sedangkan sedangkan pendapatan rumah tangga dan aset tidak signifikan. Umur dan jumlah anggota berpengaruh negatif terhadap aksesibilitas pangan rumah tangga tidak alih fungsi. Semakin tua umur maka semakin kecil peluang rumah tangga tidak alih fungsi untuk memiliki 
TABEL 6. RATA-RATA PENGELUARAN PANGAN MENURUT KOMODITI DAN ALIH FUNGSI LAHAN

\begin{tabular}{|c|c|c|c|c|c|c|c|}
\hline \multirow{3}{*}{ Keterangan } & \multicolumn{4}{|c|}{ Aksesibilitas Pangan } & & \multirow{3}{*}{ T hitung } \\
\hline & \multicolumn{2}{|c|}{ Baik } & \multicolumn{2}{|l|}{ Tidak } & & & \\
\hline & Rp/minggu & $\%$ & Rp/minggu & $\%$ & Rp/minggu & $\%$ & \\
\hline Beras & 50.343 & 43,39 & 77.600 & 45,54 & 58.520 & 44,22 & $-8,6320^{* * *}$ \\
\hline Umbi-umbian & 6.333 & 5,46 & - & - & 6.333 & 4,79 & - \\
\hline Ikan & 12.667 & 10,92 & - & - & 12.667 & 9,57 & - \\
\hline Daging & 8.370 & 7,21 & 12,000 & 7,04 & 9.030 & 6,82 & $-4,2572^{* * *}$ \\
\hline Telur & 7.234 & 6,23 & 8.400 & 4,93 & 7.589 & 5,73 & $-1,6758$ \\
\hline Susu & 5.778 & 4,98 & - & - & 5.778 & 4,37 & - \\
\hline Sayuran & 6.741 & 5,81 & 6.100 & 3,58 & 6.548 & 4,95 & 1,4910 \\
\hline Buah-buahan & 20.479 & 17,65 & 38.000 & 22,30 & 4.912 & 3,71 & $-7,0557^{* * *}$ \\
\hline Tahu-Tempe & 4.874 & 4,20 & 5.000 & 2,93 & 27.305 & 20,63 & $-0,4585$ \\
\hline Minyak Goreng & 7.654 & 6,60 & 7.800 & 4,58 & 7.699 & 5,82 & 0,3295 \\
\hline Kelapa butir & 2,048 & 1,76 & - & - & 2.048 & 1,55 & - \\
\hline Gula & 7.079 & 6,10 & 7.200 & 4,23 & 7.115 & 5,38 & $-0,2916$ \\
\hline Teh-Kopi & 3.364 & 2,90 & 2.571 & 1,51 & 3.108 & 2,35 & $3,2015^{* * *}$ \\
\hline Bumbu & 1.743 & 1,50 & 1.300 & 0,76 & 1.586 & 1,20 & $4,4127^{* * *}$ \\
\hline Mie instan & 14.273 & 12,30 & 12.000 & 7,04 & 13.923 & 10,52 & 0,6534 \\
\hline Mie basah & 2.636 & 2,27 & 3.000 & 1,76 & 2.765 & 2,09 & $-1,0280$ \\
\hline Karak-Krupuk & 1.725 & 1,49 & 2.000 & 1,17 & 1.800 & 1,36 & $-1,3125$ \\
\hline Makanan Jadi & 16.462 & 12,96 & 29.000 & 21,07 & 21.913 & 16,56 & $-1,2495$ \\
\hline Roti & 3.000 & 2,59 & - & - & 3.000 & 2,27 & - \\
\hline Air galon & 9.000 & 7,76 & 12.200 & 7,04 & 10.000 & 7,56 & $-2,3094^{* *}$ \\
\hline Rokok & 6.416 & 5,53 & 6.667 & 3,91 & 6.497 & 4,91 & $-1,0212$ \\
\hline Jumlah & 116.018 & & 170.400 & & 132.333 & & $12,8783^{* * *}$ \\
\hline
\end{tabular}

TABEL 7. HASIL ANALISIS REGRESI FAKTOR YANG MEMPENGARUHI PENGELUARAN PANGAN

\begin{tabular}{lllll}
\hline \multirow{2}{*}{ Nama Variabel } & \multirow{2}{*}{ Notasi } & \multicolumn{2}{l}{ Koefisien Regresi } & \multirow{2}{*}{ Total } \\
& & Tidak & Alih & \\
\hline Konstanta & a & $4,3795^{* * *}$ & $5,1538^{* * *}$ & $5,5296^{* * *}$ \\
Alih fungsi : tidak alih & ALIH & & & $-0,1068^{* * *}$ \\
Umur & LUM & $0,5654^{* *}$ & $0,5282^{* *}$ & $0,4288^{* *}$ \\
Jumlah anggota rumah tangga & UANG & $0,1075^{\text {ts }}$ & $0,1244^{*}$ & $0,0792^{*}$ \\
Tingkat pendidikan : SMTA ke atas & DIK & $0,0407^{\text {ts }}$ & $0,0399^{\text {ts }}$ & $0,0149^{\text {ts }}$ \\
Pendapatan usahatani & LPUSTAN & $-0,0942^{*}$ & & $-0,0390^{\text {ts }}$ \\
Pendapatan rumah tangga & LPEND & $0,0782^{\text {ts }}$ & $1,16311^{\mathrm{s}}$ & $0,0915^{*}$ \\
Aset & LASET & $0,0542^{\text {ts }}$ & $0,0658^{\text {ts }}$ & $-0,1112^{* * *}$ \\
Adjusted R-squared & & 0,0490 & 0,0453 & 0,2358 \\
F-statistic & & $1,8500^{*}$ & $1,9386^{*}$ & $9,6828^{* * *}$ \\
\hline
\end{tabular}


TABEL 8. HASIL ANALISIS REGRESI FARTOR YANG MEMPENGARUHI AKSESIBILITAS PANGAN

\begin{tabular}{lllll}
\hline Nama Variabel & \multirow{2}{*}{ Notasi } & \multicolumn{2}{l}{ Koefisien Regresi } & \\
& Tidak & Alih & Total \\
\hline Konstanta & aa & $13,7672^{* *}$ & $12,0643^{* *}$ & $9,9810^{*}$ \\
Alih fungsi : tidak alih & ALIH & & & $3,7318^{* * *}$ \\
Umur & UM & $-0,2184^{* * *}$ & $-0,1950^{* * *}$ & $-0,2318^{* * *}$ \\
Jumlah anggota rumah tangga & JANG & $-1,9180^{*}$ & $1,1869^{\text {ts }}$ & $-2,0771^{* *}$ \\
Tingkat pendidikan : & DIK & $1,4207^{*}$ & $-2,0011^{* *}$ & $1,4143^{*}$ \\
SMTA ke atas & PUSTAN & $0,000001^{*}$ & & $0,0000009^{\text {ts }}$ \\
Pendapatan usahatani & PEND & $-0,000001^{\text {ts }}$ & $0,0000007^{\text {ts }}$ & $-0,0000006^{\text {ts }}$ \\
Pendapatan rumah tangga & ASET & $-0,00000002^{\text {ts }}$ & $-0,00000001^{\text {ts }}$ & $0,00000005^{* * *}$ \\
Aset & & 0,2608 & 0,2363 & 0,6265 \\
MCFadden R-squared & & $26,1024^{* * *}$ & $23,6446^{* * *}$ & $153,0738^{* * *}$ \\
\hline LR statistic & & &
\end{tabular}

Keterangan : ${ }^{* * *}$ signifikan $1 \%,{ }^{* *}$ signifikan $5 \%,{ }^{*}$ signifikan $10 \%$, ts $=$ tidak signifikan

akses pangan baik. semakin banyak jumlah anggota rumah tangga maka semakin kecil peluang rumah tangga untuk memiliki akses pangan baik. Tingkat pendidikan berpengaruh positif terhadap aksesibilitas pangan rumah tangga tidak alih fungsi. Peluang akses pangan baik pada rumah tangga dengan tingkat pendidikan SMTA ke atas lebih besar dibanding dengan rumah tangga dengan tingkat pendidikan SMTP ke bawah. Pendapatan usahatani berpengaruh positif terhadap aksesibilitas pangan rumah tangga tidak alih fungsi. Semakin tinggi nilai aset maka semakin besar peluang rumah tangga untuk memiliki akses pangan baik.

Hasil analisis regresi logit terhadap faktor penentu aksesibilitas pangan pada rumah tangga alih fungsi (tabel 8) menunjukkan variabel umur, dan tingkat pendidikan adalah signifikan berpengaruh terhadap aksesibilitas pangan rumah tangga alih fungsi (peluang akses pangan baik atau akses pangan tidak baik). Umur berpengaruh negatif terhadap aksesibilitas pangan rumah tangga alih fungsi. Semakin tua umur maka semakin kecil peluang rumah tangga untuk memiliki akses pangan baik. Tingkat pendidikan berpengaruh negatif terhadap aksesibilitas pangan rumah tangga alih fungsi. Peluang akses pangan baik pada rumah tangga dengan tingkat pendidikan SMTA ke atas lebih kecil dibanding dengan rumah tangga dengan tingkat pendidikan SMTP ke bawah.

Hasil analisis regresi logit terhadap faktor penentu aksesibilitas pangan untuk total rumah tangga (table 8) menunjukkan variabel alih fungsi, umur, jumlah anggota rumah tangga dan aset adalah signifikan berpengaruh terhadap aksesibilitas pangan rumah tangga (peluang akses pangan baik atau akses pangan tidak baik), sedangkan pendapatan usahatani dan pendapatan rumah tangga tidak signifikan. Alih fungsi berpengaruh positif terhadap aksesibilitas pangan rumah tangga, rumah tangga yang tidak melakukan alih fungsi mempunyai peluang lebih besar untuk memiliki akses pangan baik dibanding dengan rumah tangga yang melakukan alih fungsi. Umur dan jumlah anggita rumah tangga berpengaruh negatif terhadap aksesibilitas pangan rumah tangga. Semakin tua umur maka semakin kecil peluang rumah tangga untuk memiliki akses pangan baik. Semakin banyak jumlah anggota rumah tangga maka semakin kecil peluang rumah tangga untuk memiliki akses pangan baik. Tingkat pendidikan berpengaruh positif terhadap aksesibilitas pangan rumah tangga. Peluang akses pangan baik pada rumah tangga dengan tingkat pendidikan SMTA ke atas lebih besar dibanding dengan rumah tangga dengan tingkat pendidikan SMTP ke bawah. Aset berpengaruh positif terhadap aksesibilitas pangan rumah tangga. Semakin tinggi nilai aset maka semakin besar peluang rumah tangga untuk memiliki akses pangan baik.

Pengaruh masing-masing variabel independen terhadap aksesibilitas pangan rumah tangga dilihat dari odds ratio. Hasil perhitungan odds ratio disajikan pada tabel 9. 
TABEL 9. ODDS RATIO KOEFIIIEN REGRESI AKSESIBILITAS PANGAN RUMAH TANGGA

\begin{tabular}{lllll}
\hline \multirow{2}{*}{ Nama Variabel } & \multirow{2}{*}{ Notasi } & \multicolumn{2}{l}{ Koefisien Regresi } \\
& Tidak & Alih & Total \\
\hline Konstanta & aa & $952866^{* *}$ & $173560^{* *}$ & $21611^{*}$ \\
Alih fungsi : tidak alih & ALIH & & & $41,75^{* * *}$ \\
Umur & UM & $0,80^{* * *}$ & $0,82^{* * *}$ & $0,79^{* * *}$ \\
Jumlah anggota rumah tangga & JANG & $0,15^{*}$ & $3,28^{\text {ts }}$ & $0,13^{* *}$ \\
Tingkat pendidikan : SMTA ke atas & DIK & $4,14^{*}$ & $0,14^{* *}$ & $4,11^{*}$ \\
Pendapatan usahatani & PUSTAN & $1,0^{*}$ & & $1,0^{\text {ts }}$ \\
Pendapatan rumah tangga & PEND & $1,0^{\text {ts }}$ & $1,0^{\text {ts }}$ & $1,0^{\text {ts }}$ \\
Aset & ASET & $1,0^{\text {ts }}$ & $1,0^{\text {ts }}$ & $1,0^{* * *}$ \\
\hline
\end{tabular}

Keterangan : ${ }^{* * *}$ signifikan $1 \%,{ }^{* *}$ signifikan $5 \%,{ }^{*}$ signifikan $10 \%$, ts = tidak signifikan

Berdasar tabel 9, pada total rumah tangga, odds ratio variabel alih fungsi sebesar 41,75 berarti rumah tangga tidak alih fungsi lahan mempunyai peluang lebih besar 41,75 untuk akses pangan baik dibanding rumah tangga alih fungsi lahan, dengan menganggap variabel lain konstan. Untuk variabel umur pada ketiga kelompok rumah tangga menunjukkan nilai odds ratio yang hampir sama sekitar 0,8 berarti peningkatan umur dengan satu persen maka kecenderungan rumah tangga untuk akses pangan baik berkurang sebesar 0,79 kali, dengan menganggap variabel lain konstan. Begitu juga variabel tingkat pendidikan menunjukkan nilai odds ratio yang hampir sama sekitar 4,11 berarti rumah tangga tingkat pendidikan SMTA ke atas mempunyai peluang lebih besar 41,11 kali untuk akses pangan baik dibanding rumah tangga tingkat pendidikan SMTP ke bawah, dengan menganggap variabel lain konstan.

Besarnya peluang rumah tangga untuk akses pangan baik dapat dihitung dengan memasukkan data variabel independen yang secara statistik signifikan ke dalam persamaan regresi hasil estimasi. Hasil perhitungan pada rumah tangga tidak alih fungsi lahan dengan umur 64 tahun, jumlah anggota rumah tangga 2 orang, tingkat pendidikan SMTA ke atas dan nilai aset yang dimiliki sebesar Rp 20.728.850, mempunyai peluang untuk akses pangan baik sebesar $5,22 \%$.

\section{KESIMPULAN}

Temuan bahwa sumber pendapatan utama rumah tangga tidak alih fungsi maupun alih fungsi berasal dari usahatani, bahwa rumah tangga yang tidak alih fungsi mempunyai peluang lebih besar untuk akses pangan baik, dan bahwa pendapatan usahatani pada rumah tangga tidak alih fungsi berpengaruh positif terhadap peluang untuk mempunyai akses pangan baik, maka pemerintah hendaknya menghentikan alih fungsi lahan atau mengendalikan alih fungsi lahan. Upaya pengendalian ini tidak saja pada pembuatan aturan saja, namun juga mengawal dan memonitor pelaksanaan peraturan tersebut untuk menjamin tidak terjadinya alih fungsi lahan. Pemberian insentif pada rumah tangga petani yang mengusahakan budidaya tani di lahan produktif perlu juga diupayakan, sehingga mereka tidak mengalihfungsikan lahannya.

\section{DAFTAR PUSTAKA}

Afandi, Muhamad Nur. 2011. "Analisis Kebijakan Alih Fungsi Lahan Pertanian Terhadap Ketahanan Pangan di Jawa Barat". Jurnal Ilmu Administrasi. Vol. VIII No.2 Agustus 2011.

Ginting, Memberita. 2005. "Faktor-faktor yang Mempengaruhi Alih Fungsi Lahan Pertanian Padi Sawah Terhadap Pendapatan Petani (Studi Kasus di Desa Munte Kabuoaten Karo)". Tesis. USU Repository. 2007. http://google.com. Diakses tanggal 7 Desember 2012

Irawan, Bambang. 2005. "Konversi Lahan Sawah :

Potensi Dampak, Pola Pemanfaatannya, dan Faktor Determinan”. Forum Penelitian Agro Ekonomi. Volume 23 No. 1, Juli $2005: 1$ - 18.

Jonsson, U. and Toole, D. 1991. Household Food Security and Nutrition: A Conceptual Analysis. UNICEF mimeo. 
Maxwell, D; C. Levin; M.A. Klemeseau; M.Rull; S.Morris and C.Aliadeke. 2000. "Urban Livelihoods and Food Nutrition Security in Greater Accra,Ghana”. IFPRI in Collaborative with Noguchi Memorial for Medical Research and World Health Organization. Research Report No.112. Washington, D.C.

Santosa, I Gusti Ngurah; Gede Menaka Adnyana dan I Ketut Kartha Dinata. 2011. "Dampak Alih Fungsi Lahan Sawah Terhadap Ketahanan Pangan Beras". Prosiding Seminar Nasional Budidaya Pertanian : Urgensi dan Strategi Pengendalian Alih Fungsi Lahan Pertanian. Bengkulu 7 Juli 2011. ISBN 978-602-19247-0-9. 